\title{
BLUE STAIN DEVELOPMENT OF SCOTS PINE (PINUS SYLVESTRIS L.) ROUNDWOOD AND ITS INFLUENCING FACTORS
}

\author{
Mareks Millers, Jānis Magaznieks, Zelma Gžibovska \\ Latvia University of Agriculture \\ mareks.millers@inbox.lv
}

\begin{abstract}
The normal wood color changes due to the biochemical reactions as well as under the fungal exposure. Some of these fungi during all the exposure time cause only a discoloration (staining fungi), others change not only color, but also the structure of the wood in its further development (wood destructing fungi).

The development of blue stain in sapwood of pine roundwood and its influencing factors were studied in the springsummer period of 2016 (April, May and June) in the districts of Nica, Jelgava and Daugavpils. 650 discs from pine $\log$ end planes were prepared in order to evaluate the influence of harvesting type, spreading type of fungi spores, placement in pile, storage duration, diameter, distance from the end plane, daily average temperatures, precipitation amount and relative humidity on blue stain of sapwood and rot development.

The most important factors influencing the blue stain development on pine roundwood during the storage are the harvesting type of roundwood, spreading type of fungal spores, placement in pile, storage duration, diameter, distance from the end plane, daily average temperature and amount of precipitation. By evaluating the daily average temperatures, it was concluded that blue stain of sapwood begins to develop when the average daily temperature reaches $+5 \ldots+6{ }^{\circ} \mathrm{C}$. But when the average daily temperatures reach $+10{ }^{\circ} \mathrm{C}$, depending on the harvesting type (chainsaw or harvester) and spreading type of the fungal spores (via air or bark beetle assistance) the first signs of blue stain may occur from 10 to 42 days of storage.
\end{abstract}

Key words: pine roundwood, blue stain, bark beetles.

\section{Introduction}

Blue stain is the most common cause of wood discoloration and it mainly affects conifer sapwood (Uzunovic et al., 2008). Blue stain is usually found on coniferous wood, like Scots pine (also Abies, Picea, Pseudotsuga, and other genus, respectively), more rarely blue stain can be found on deciduous trees (Fagus, Populus, Quercus, Fraxinus genus, etc.).

Blue stain causing fungi belong to the following genera: Alternaria, Cadophora, Diplodia, Discula, Graphium, Hormodendron, Hormonemia etc. These fungi are using the starch and sugars available in the sapwood. They cannot develop in heartwood, since there are no needed nutrients (Вакин et al., 1980).

Roundwood after logging is stored in the forest near the road from where it is later transported to the processing sites. Timber storage duration in such cases is uncertain both in the forest near the road and in the stowage area, so sometimes these materials remain vulnerable to various types of damage.

Logs that are stored unprotected against different types of damage for a long time, remain susceptible to biological staining, as these conditions are a favorable environment for microbial development. Such conditions allow different types of bacteria directly access the sapwood part, rather than the core, because sapwood is relatively rich in nutrients and contains no phenols and timber extractive matter, which hinders the growth of microorganisms. Although unstained timber can accommodate different types of organisms, it is important to determine the cause of each type of discoloration. In order to prevent future damages of the wood, it is necessary to distinguish between blue stain that is caused by bacteria or mold spots (Uzunovic et al., 2008).

Blue stain fungi are transmitted and transferred by insects that contribute to their release on the unprotected timber, where they act as pioneer species creating colonies. These fungi have little competition with other organisms, the impact of which is insignificant (Uzunovic et al., 2008).

Wood with an intact bark usually is not affected by blue stain fungi as fast as wood with bark defects, as blue stain has access to the outer part of sapwood through the damages of the bark.

The blue stain on logs usually appear in the form of wedge-shaped stripes in blue or gray color. In some cases, the blue stain has expanded all over the sapwood part. It is sometimes fully visible from the round timber terminal plane.

Blue stain fungus can spread even when there is only one infected log in the stack, because under favorable conditions blue stain fungus is able to spread at high speed, infecting most of the sawn timber, which is located in the stack. This spread can be slowed down or completely stopped, by drying wood in outdoor conditions so that they are not influenced by precipitation (Uzunovic et al., 2008).

Yang \& Beauregard, (2001) conducted a study in the eastern Canada on seasonal effect on the development of the blue stain fungi in roundwood during the storage period. They concluded that the best time for the timber storage is winter. At this time of the year the development of blue stain fungi was 
significantly reduced, but it rapidly accelerated after the winter period, starting from April. In the spring period, a significant development of the blue stain was observed after four-week long storage period. This project proved the theory of poorer development of the blue stain in the logs with undamaged bark, as peeled or rubbed logs suffered from blue stain much more. In cases when the timber implementation for various reasons has stopped and the blue stain begins to appear, logs must be immediately treated with certified chemicals that stop the fungus from spreading. When roundwood is drying, the spores of blue stain fungi do not develop if the timber moisture is not higher than $19 \%$, except if the relative humidity remains very high for a long time (above $90 \%$ ).

A big challenge for timber quality after storms is drying out. In addition to the timber dryness, drying also contributes to the spread of wood living fungi. Blue stain fungal penetration becomes a problem (spread through the air or with the help of insects) at the time when the tree is cut down. While storage rot is a relatively small problem in the first season, it becomes important in subsequent seasons (Tamminen, 1979).

Forest and timber industry is experiencing huge losses due to blue stain fungi. Blue stain lesions usually occur in the sapwood and represent only a "cosmetic problem" without serious changes of technical characteristics of the wood. Despite this, the timber with blue stain means that its market value will be lower. Friedl (2004) considered these losses in Austria after wood processing in mills and found that they reach more than 35 million euros per year. The acceptable discoloration level of blue stain fungi is dependent on the regulation of the specific roundwood entry place on sapwood discoloration depth.

The aim of this research was to determine the blue stain development of Scots pine (Pinus sylvestris L.) and its influencing factors. By having warmer spring and autumn, forest logging is possible all year round with a higher intensity, after that fast harvesting, forwarding and roundwood transportation should follow.
The study results can be used by forest managers, timber logging companies and timber logistics planners, who can plan logging operations and transportation of roundwood more precisely based on the knowledge about factors that influence roundwood quality changes during storage and their threshold values, in that way avoiding or minimizing the decrease of timber value reduction.

\section{Materials and Methods}

Factors affecting pine round timber blue stain development were analyzed in the spring - summer period (April, May and June) of 2016. Control cuttings for determination of blue stain development were carried out in four pine round assortment open storages in Nica, Jelgava and Daugavpils region. To keep the forest climate, all storages were placed in the forest under the tree crowns.

650 sample discs were prepared from pine round wood ends in order to evaluate the preparation type, side surface damage type, type of fungal spore spread, placement in the storage, storage length, diameter, distance from the end plane, the daily average temperature, precipitation amount and relative humidity effects on the blue stain development.

Sample storage consists of $26-32$ (on average 30 ) round assortments with $10-30 \mathrm{~cm}$ in diameter and 1 meter in length (see Fig. 1). As it is known that sapwood discoloration and crooks mainly are developing from the end plane, 1 meter long assortments are enough to evaluate the quality changes from round timber end planes.

The evaluation of round timber placement in the storages:

- $1-9$ assortments are characterizing the quality changes of the bottom of the storage (round timber placement on the ground);

- $11-16$ and 19 - 23 assortments are characterizing the quality changes in the middle of the storage;

- 10, 17, 18 and 24 - 30 assortments are characterizing the quality changes on the top of the storage.

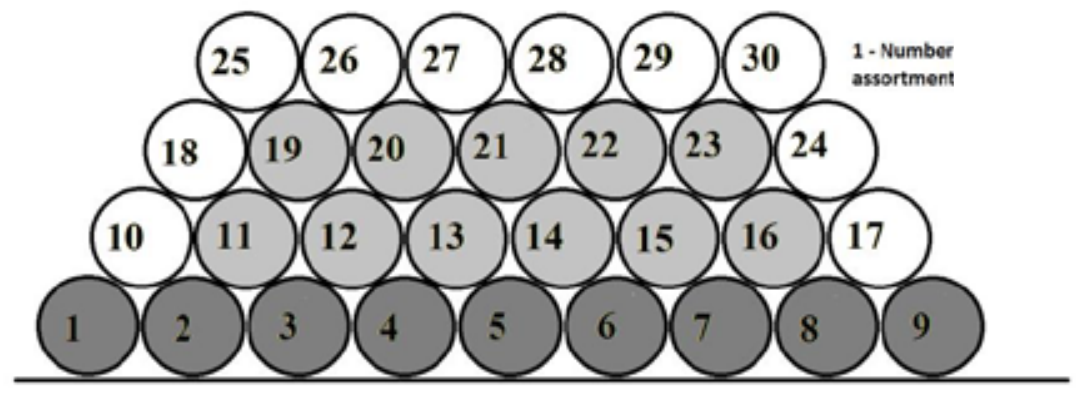

$1-30-$ number of the $\log$

Dark grey - ground assortments

Light grey - middle assortments White - top assortments

Figure 1. The scheme of assortment emplacement. 
$3-5 \mathrm{~mm} \mathrm{50mm} \mathrm{100mm} \mathrm{150mm} \mathrm{200mm}$

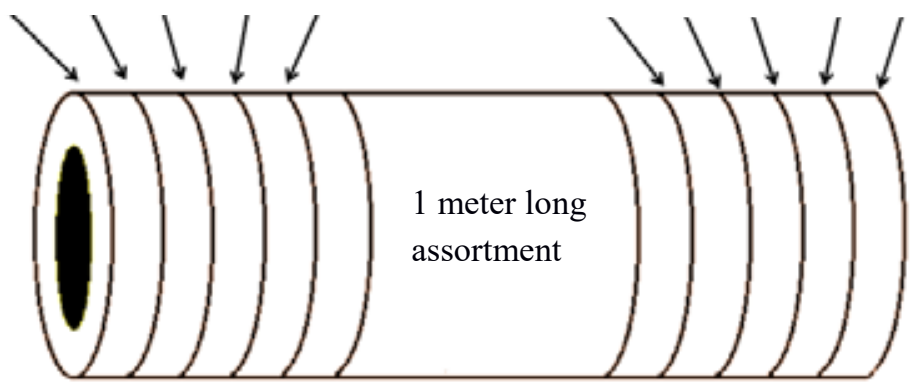

Figure 2. Roundwood cross-cutting section length.
In order to assess variety of preparation ways, four timber storages were created in the same time in each plot with different damages of side surface.

- Control - assortments without side surface damages.

- Damaged bark - assortments with the side surface of the bark bruised over the entire length.

- Harvester spike roller damages - assortments that have damages from harvester pike roller, but do not have bruised bark made by debarking knives.

- Harvester spike roller and bark damages assortments with bruised bark and damaged side surface by harvester spike roller.

The inspection of pine round assortments was carried out at least once a week, control cuttings were started after 7 weeks of storage, but replications after every $2-3$ weeks. In every control cutting around 8-12 round assortments for determination of blue stain were examined $-2-3$ from the ground assortments, 3-4 from the middle and top assortments.

Discs of the assortment were sawn off in one survey, as shown in the scheme (Fig. 2). For the first disc on the outside only sapwood was sawn $3-5 \mathrm{~mm}$ in depth in order to assess the quality requirements of assortments at purchasing. Every subsequent disc was sawn in $50 \mathrm{~mm}$.

After preparation of sample discs it is necessary to mark sapwood discoloration border. Further the numbering for taking photos is applied - the number shows the distance in $\mathrm{cm}$ from the end plane. To describe the proportion of blue stain, it is necessary to determine the percentage of sapwood discoloration by excluding heartwood. Therefore, sapwood and blue stain basal area of sample discs were calculated by using special image processing software 'ImageJ'. The total area of sapwood and blue stain was marked with different colors already in the forest. By establishing images with different distance from the end plane, we could assess damage intensity in the longitudinal direction. For further data analysis for every sample disc we made the measurement of heartwood basal area, sapwood basal area and area of discoloration. Lower average air temperature results in longer storage periods, whereas higher average air temperature results in shorter storage periods.

In order to get meteorological data, temperature and precipitation were obtained from www.meteo.lv by using data of the nearest meteorological station. The sum of positive temperature and sum of precipitation during storage period were used.

Two independent sample mean values \pm 2 standard errors are characterized by a $95 \%$ confidence interval. If two independent samples with $95 \%$ confidence intervals overlap with each other, then the difference between them will not be statistically significant. To determine the significance of multiple factors, multiple factor linear regression was used. For this analysis IBM SPSS Statistics 20 was used.

\section{Results and Discussion}

To prevent the development of blue stain, it is necessary to maintain unfavorable conditions for the growth of fungi (keeping timber dry, temperatures above or below the ideal temperature for fungi development and protecting wood against insect attacks). Blue stain fungi are distributed with spores which are produced in very large quantities. Although the spores of other fungi are typically carried by the wind, the spores of blue stain fungi are sticky and are transmitted by insects. Ending up in nutritious environment these spores begin to grow rapidly. Blue stain spores can survive, but are not able to grow in wood with a humidity level of $20 \%$ or less, as well as in high or low temperatures. Temperatures above $+65^{\circ} \mathrm{C}$ are lethal for blue stain fungi (Simpson, 1991).

One of the possibilities for the presentation of results is to analyze and describe the sapwood discoloration development based on the length of storage. It is well known that climate is changing there are regular temperature fluctuations. We have found the way of analysis based on the sums of daily average temperature. In this way, the production companies will be able to plan logging, logistics and storage 
Development of the blue stain depending on the average daily temperature, storage length, preparation type and spreading type of fungi spores

\begin{tabular}{|c|c|c|}
\hline \multirow[t]{2}{*}{ Daily average air temperature, ${ }^{\circ} \mathrm{C}$} & First signs of blue stain & $\begin{array}{l}\text { Blue stain observed on all round } \\
\text { assortments }\end{array}$ \\
\hline & \multicolumn{2}{|c|}{ Storage length, days } \\
\hline \multicolumn{3}{|c|}{ Prepared with the chainsaw and the fungal spores spread by air } \\
\hline 6 & 70 & 101 \\
\hline 10 & 42 & 60 \\
\hline 14 & 30 & 43 \\
\hline 18 & 23 & 34 \\
\hline \multicolumn{3}{|c|}{ Prepared with the harvester and the fungal spores spread by air } \\
\hline 6 & 50 & 94 \\
\hline 10 & 30 & 56 \\
\hline 14 & 21 & 40 \\
\hline 18 & 17 & 31 \\
\hline \multicolumn{3}{|c|}{ Prepared with the chainsaw and the fungal spores spread by bark beetle } \\
\hline 6 & 17 & 69 \\
\hline 10 & 10 & 41 \\
\hline 14 & 7 & 29 \\
\hline 18 & 6 & 23 \\
\hline \multicolumn{3}{|c|}{ Prepared with the harvester and the fungal spores spread by bark beetle } \\
\hline 6 & 23 & 75 \\
\hline 10 & 14 & 45 \\
\hline 14 & 10 & 32 \\
\hline 18 & 8 & 25 \\
\hline
\end{tabular}

of round timber based on simple climatic indicator value analysis, thus optimizing the maximum timber logging, delivery and storage time.

By evaluating the daily average temperatures, it was concluded that the sapwood discoloration begins to develop when the average daily air temperature rises to $+5 \ldots+6{ }^{\circ} \mathrm{C}$. Table 1 shows the development of blue stain depending on the average daily temperature, storage length, preparation type and spreading type of fungal spores. By analyzing a simple influencing factor such as air temperature, it can be concluded that by evaluating other influencing factors at the same average daily temperature, the first signs may appear within 6 to 23 days (daily average air temperature 18 $\left.{ }^{\circ} \mathrm{C}\right)$. At lower average daily air temperature $\left(10{ }^{\circ} \mathrm{C}\right)$, the first signs of blue stain can appear between 10 to 42 days.

If logging is done in spring (bark beetle flying time), from a reduction in quality point of view, the most dangerous is to prepare round assortments with the chainsaw by not removing bark, but in the summer time with harvester (average daily temperature $-18{ }^{\circ} \mathrm{C}$ ) when debarked round assortments directly contribute to more intensive development of the blue stain. At this time already after 23-34 days of storage blue stain will be seen on all the round assortments.

There are many connections between bark beetles and conifer fungi, mainly including beetle species Ips and Dendroctonus and fungal species Ceratocystis and Ophiostoma (Webber \& Gibbs, 1989). Different kinds of insects are inhabiting, breeding and feeding in the same wood together with blue stain fungi and other micro-organisms. Ophiostoma fungus rapidly attach to arthropods which promotes the spread of fungi (Blackwell, 1994). Blue stain fungal spores can be transmitted both through insect intestinal tract and the outer shells, which make a large part of insects the vectors of blue stain (Borden, 1995).

Figure 3 shows the sapwood discoloration area (\%) depending on distance from the end plane, storage length and fungal spore spreading. This figure shows a very interesting trend for both types of fungal spore spread $-5 \mathrm{~mm}$ away from the end plane the proportion of sapwood discoloration is similar, while 10 and $15 \mathrm{~cm}$ from the end planes, the discoloration proportion is significantly higher when fungal spores are spread by bark beetle. This is explained by the 


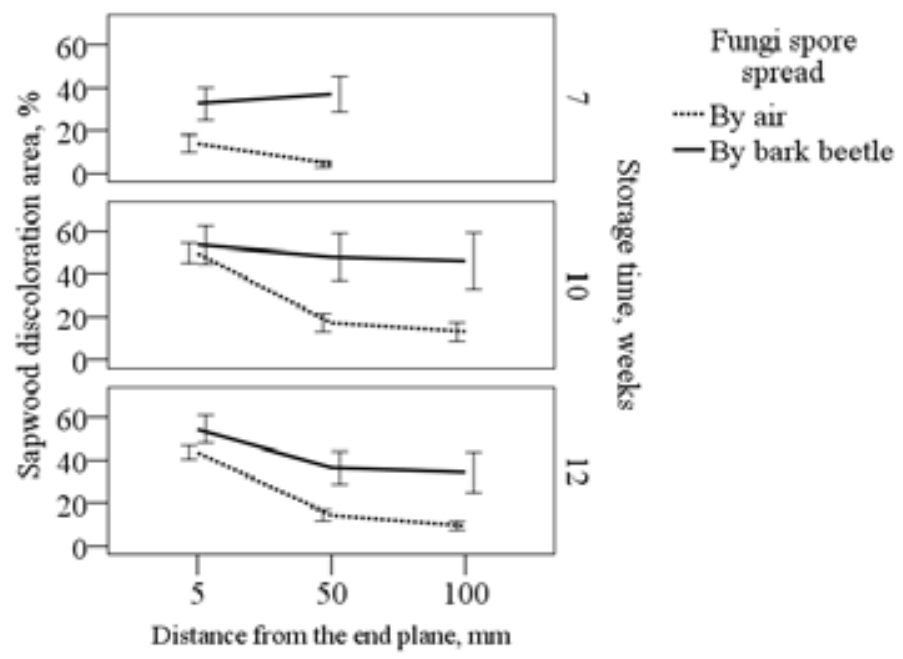

Figure 3. Sapwood discoloration area (\%) depending on distance from the end plane, storage length and fungal spore spreading (with \pm 2 standard error).

fact that insects make the aisles in round assortments' bark in all length by infecting the entire assortment and discoloration develops equally, regardless of the distance from the end plane. After seven weeks of storage, there is a trend to increase in the proportion of sapwood discoloration in the direction from the end plane.

Mechanized logging damages the side surface of the timber, uncovering and rubbing the tree bark, as well as creating up to a few centimeters deep gaps and penetrations with harvester roller spikes. And in this way the damaged timber gets exposed to the development of rot and discoloration (Uzunovic et al., 2004, Lee \& Gibbs, 1996).

Figure 4 shows the sapwood discoloration area (\%) depending on distance from the end plane, storage length and preparation type. Preparation type does not show significant influence on sapwood discoloration area development. Sapwood discoloration proportion tends to decrease from the end plane towards the middle plane.

By storing pine logs, depending on the storage length, the following discoloration development may occur:

- after 7 weeks of storage, at both $50 \mathrm{~mm}$ and $5 \mathrm{~mm}$ from the end plane the sapwood discoloration rate is around $20 \%$ and no statistically significant differences are found regarding the type of preparation;

- after 10 weeks of storage, at $5 \mathrm{~mm}$ from the end plane the discoloration proportion is ranging from $45 \%$ to $55 \%$ depending on the preparation type, at $50 \mathrm{~mm}$ from the end planes, it decreases to an average of $30 \%$, and at $100 \mathrm{~mm}$ from the end planes, it decreases slightly further to an average of $25 \%$;

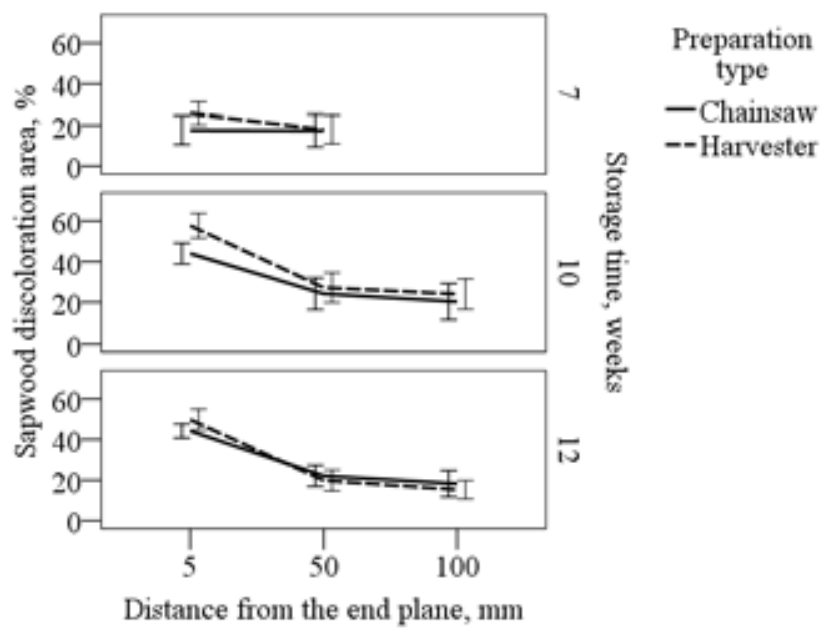

Figure 4. Sapwood discoloration area (\%) depending on distance from the end plane, storage length and preparation type (with \pm 2 standard error). 
The evaluation of significance of sapwood discoloration influencing factors

\begin{tabular}{|c|c|c|c|c|c|c|}
\hline Indicator & Coefficient & Standard error & t stat. & *p - value & $\begin{array}{c}\text { Correlation } \\
\text { coefficient } \\
(\mathrm{r})\end{array}$ & $\begin{array}{l}\text { Determination } \\
\text { coefficient }\left(\mathrm{R}^{2}\right)\end{array}$ \\
\hline \multicolumn{7}{|c|}{ Fungal spores spread by air } \\
\hline Constant & -62.126 & 9.719 & -6.392 & 0.000 & \multirow{7}{*}{0.721} & \multirow{7}{*}{0.521} \\
\hline Side surface damages & 10.865 & 3.119 & 3.483 & 0.001 & & \\
\hline Placement in the storage & 1.838 & 0.832 & 2.210 & 0.028 & & \\
\hline Diameter, cm & -0.286 & 0.117 & -2.453 & 0.015 & & \\
\hline $\begin{array}{l}\text { Distance from the end } \\
\text { plane, } \mathrm{mm}\end{array}$ & -0.358 & 0.019 & -19.234 & 0.000 & & \\
\hline $\begin{array}{l}\text { Average daily temperature } \\
\text { sum }\end{array}$ & 0.253 & 0.023 & 10.977 & 0.000 & & \\
\hline Precipitation sum, mm & -0.847 & 0.084 & -10.106 & 0.000 & & \\
\hline \multicolumn{7}{|c|}{ Fungal spores spread by bark beetles } \\
\hline Constant & 29.282 & 15.243 & 1.921 & 0.056 & \multirow{6}{*}{0.615} & \multirow{6}{*}{0.378} \\
\hline Side surface damages & 20.696 & 5.885 & 3.517 & 0.001 & & \\
\hline Diamters, $\mathrm{cm}$ & -2.338 & 0.282 & -8.288 & 0.000 & & \\
\hline $\begin{array}{l}\text { Distance from the end } \\
\text { plane, } \mathrm{mm}\end{array}$ & -0.125 & 0.038 & -3.309 & 0.001 & & \\
\hline $\begin{array}{l}\text { Average daily temperature } \\
\text { sum }\end{array}$ & 0.165 & 0.042 & 3.899 & 0.000 & & \\
\hline Precipitation sum, mm & -0.531 & 0.161 & -3.303 & 0.001 & & \\
\hline
\end{tabular}

If $\mathrm{p}$ values are smaller than 0.05 , influence of the factor is significant.

- after 12 weeks of storage, at $5 \mathrm{~mm}$ from the end plane the discoloration proportion is around $40 \%$, at $50 \mathrm{~mm}$ from the end planes it decreases to $22 \%$ and at $100 \mathrm{~mm}$ away from the end plane it decreases slightly further to an average of $20 \%$.

In order to more fully describe the sapwood discoloration proportional changes in the springsummer period, the multiple linear regression analysis is used to analyze the wider effect of influencing factors.

The general task of regression analysis is to study the relationship between the dependent variable (sapwood discoloration proportion) and predictors (side surface damage, placement in the storage, diameter of round assortments, distance from the end plane, the daily average temperature and amount of precipitation) and to evaluate the correlation of predictors. By analyzing the round assortment quality mitigating factors, a table 8.3.3 is made with values of factors influencing the development of sapwood discoloration, which will be used later for setting up the algorithm. For pine assortments two sets of factor values are created influencing the development of sapwood discoloration:

- Fungal spores spread by the air;
- Fungal spores spread by bark beetles.

By using values of these factors, it is possible to predict the trends if the round assortment quality changes. Factors that significantly affect the sapwood discoloration when fungal spores spread by air, are: a side surface damage, placement in the pile, round assortment diameter, distance from the end plane, the average daily temperature and precipitation sum. When fungal spores are spread by bark beetle, there is a significant impact on all of the above-mentioned factors except for placement in the pile. Both sets of factors show average correlation.

Determination coefficient $\mathrm{R}^{2}$ for linear regression ranges from 0.371 to 0.521 , indicating that from 37 to $52 \%$ of the discoloration development cases of pine round assortments can be explained by these factors (see Table 2).

\section{Conclusions}

1. The main factors affecting the share of crosssectional area of sapwood discoloration in round assortments during storage are preparation type, fungal spore spread, placement in the storage, storage time, diameter, distance from the end plane, the daily average air temperature and precipitation amount. 
2. With average daily air temperature reaching $+18^{\circ} \mathrm{C}$, depending on the preparation type of pine round wood (chainsaw or harvester) and fungal spore spread (by air or bark beetle), the first signs of blue stain may appear after 6 to 23 days of storage. However, at average daily temperature of $+10{ }^{\circ} \mathrm{C}$, depending on the preparation type and distribution way of fungal spores, the first signs of blue stain may appear after 10 to 42 days of storage.

3. Fungal spore spread by air causes sapwood discoloration reach $17 \%$ after 7 weeks of storage, but in the case of fungal spore spread by bark beetle - the average discoloration is significantly higher and reaches $37 \%$.

\section{References}

1. Blackwell, M. (1994). Minute mycological mysteries: the influence of arthropods on the lives of fungi. Mycologia, 86(1), pp. $1-17$.

2. Borden, J.H. (1995). Forest Insect Pests in Canada. Natural Resources Canada, Ottawa. In Development and use of semiochemicals against bark and timber beetles. Armstrong, J.A., \& W.G.H. Ives (Eds.) Forest Insect Pests in Canada. Natural Resources Canada, Canadian Forest Service, Ottaea, Ontario, pp. 431 449.

3. Friedl, K. (2004). Bläue an Fichtenrundholz-Schadensquantifizierung und auswirkung auf die lagerungsdauer (Blue stain on pinewood - damage quantification and impact on the storage period). FORMEC, Gmunden oberösterreich, Retrieved December 4, 2016, from: https:/www.formec.org/images/ proceedings/2004/PA_Friedl.pdf. (in German).

4. Lee, K., \& Gibbs, J.N. (1996). An investigation of the influence of harvesting practice on the development of blue-stain in Corsican pine logs. Forestry, 69(2), pp. 137 - 141.

5. Simpson, W. (1991). Properties of wood related to drying. Dry kiln operator's manual handbook AH-188. USDA Forest Service. Forest Products Laboratory, Madison, pp. I1 - I50.

6. Tamminen, Z. (1979). Storage losses in unbarked 3 metre pulpwood of pine, spruce, birch and common alder. The Swedish University of Agricultural Siences, Department of Foret Products. Report 112. ISBN 91-576-0367-7. (in Swedish with English summary).

7. Uzunovic, A., Byrne, T., Gignac, M., \& Dian-Qing, Y. (2008). Wood Discolourations and their Prevention [online]. FPInnovations, Canada. Retrieved December 4, 2016, from: https://fpinnovations.ca/media/ publications/Documents/wood-discoloration.pdf.

8. Uzunovic, A., O’Callahan, D., \& Kreber, B. (2004). Mechanical tree havesters spread fungal inoculum onto freshly felled Canadian and New Zealand pine logs. Forest products journal, 54(11), p. 34.

9. Webber, J.F., \& Gibbs, J.N. (1989). Insect dissemination of fungal pathogens of trees [online]. Academic Press. Retrieved December 6, 2016, from: https://www.google.com/books?hl=en\&lr=\&id=DwO5_3N7s SAC\&oi=fnd\&pg=PA161\&dq=Webber + and + Gibbs, $+1989 \&$ ots $=10 X x W S z V z u \& s i g=i y U Z P m 5 C N g u T l s$ Dh9kNq662uFN8.

10. Yang, D.-Q., \& Beauregard, R. (2001). Check development on jack pine logs in Eastern Canada. Forest products journal, 51(10), p. 63.

11. Вакин, А.Т., Полубояринов, О.И., \& Соловьев, В.А. (1980). Пороки древесиньl (Defects of wood). (in Russian). 